\title{
Dynamic Relationship between Interest Rate and Tourism Stock Performance: Empirical Evidence from Egyptian Exchange Nagla Harb Sayed Ahmed
}

Alexandria University, MUST University, Egypt

\begin{abstract}
Tourism industry plays a significant role in the economic development in Egypt. Identifying the effects of macroeconomic variables on the performance of tourism companies is important and of great interest to decision-makers and investors. The main purpose of this study is to investigate the dynamic relation between interest rate and the stock performance of tourism companies, as measured by the stock price, in the Egyptian Exchange (EGX). The linear Granger causality test, Cointegration analysis and Error Correction Model (ECM) are employed to establish the relationship between the tested variables. Findings show that a unidirectional causal relationship exists between the variables evaluated from interest rate to tourism stock price. A positive longrun cointegration between the tested variables is observed and a rise in interest rate by $1 \%$ triggers stock price rise of $26.8 \%$. The coefficient of error correction indicates that $0.03 \%$ of the deviation of stock price is adjusted in the short-run. The study ends with implications for decision-makers, financial executives in tourism companies and researchers in the field.
\end{abstract}

Key Words: Monetary policy, Interest rate, Tourism company, Stock price, Egypt

\section{Introduction}

Tourism sector plays an important role in the Egyptian economy. In addition to its direct contribution to GDP, employment and foreign revenues, it impacts several industries directly and many more indirectly through tourism spending and investment. According to the World Travel \& Tourism Council (WTTC) (2019), during 2018 the Egyptian tourism industry grew by 16.5\% and its contribution to GDP hit $11.9 \%$. It provided 2.48 million jobs directly, representing $9.5 \%$ of the total employment, and added $\$ 12.2$ billion to the foreign revenues. These statistics reflect a strong recovery of the Egyptian tourism industry after a turbulent period of revolutions and political instability.

The economic reform in Egypt to face the foreign exchange crisis - which began in 2013 as the foreign currency reserve was insufficient to cover trade commitments- and the liberalization of the exchange rate, triggered higher inflation levels. A situation that required the intervention of the Central Bank of Egypt (CBE) with adjustments in the monetary policy to absorb the increased money supply (M2), and control inflation rate. That led to a decision by the CBE to raise interest rates. Interest rates have been revised several times and increased to hit their highest levels in two decades. For illustration, interest rate on loans reached $19.9 \%$ in January 2018, and interest rate on 3-month deposits reached 14.6\% in October 2017 (cbe.org.eg). Assuming that the macroeconomic conditions in general influence firms' performance and investment decisions, macroeconomic variables are expected to influence the stock market performance. Over a long period of time, investigating the interaction between interest rate and stock performance has attracted the attention of economists, financiers, practitioners, and decision makers since both variables play a crucial role in investment decisions and economic development (See for example: Asprem,1989; Arango et al., 2002; Uddin \& Alam, 2007; Amarasinghe, 2015). Few studies focused on tourism and hospitality sector to investigate this relationship in various countries. In Egypt, to the best of the researcher's knowledge, no study could yet be found to investigate the effect of monetary policy changes on tourism companies' performance in the Egyptian stock exchange (EGX). The present study is motivated by the absence of research 
papers on tourism stock performance and the factors affecting it, despite the significance of this sector and its role as a locomotive for economic growth in Egypt.

The aim of this paper is to investigate the dynamic relationship between interest rate and tourism stock performance, as measured by the stock price, and determine the effect of interest rate variation on tourism stock price in the EGX. It further seeks to provide practical implications for the findings. Monthly data on the tourism companies listed in the EGX and CBE date on interest rate are collected from June 2010 to September 2019. The results of the paper provide valuable insights for decision-makers about the tourism companies' performance and the response of stock price to changes in interest rate, and hence, the potential of tourism sector in the capital market. Executives from these particular companies will also find the results valuable for forecasting their market values and building strategies to manage their financial positions upon changes. Moreover, investors in the EGX can benefit from the results in forecasting tourism stock prices and more effectively manage their portfolios to gain higher returns.

\section{Literature Review}

Mainstream financial thinking holds that monetary policy aggregates affect the behavior of financial aggregates (Modigliani \& Cohn, 1979; Hashemzadeh \& Taylor, 1988). The relationship between stock price and interest rate is built on the assumption that investors will alter their portfolio structure between stocks and bonds according to interest rate changes. In particular, as interest rate rises capital flows switch to banks, while declining interest rate leads investors to turn to the stock market in pursuit of higher returns (Apergis \& Eleftheriou, 2002).

The Arbitrage Pricing Theory (APT) suggests that the estimated return on a capital asset may be presented as a linear function of different variables, where a beta coefficient signifies the sensitivity of the return to changes in each variable (Ross, 1976). Over a long time, many empirical studies have attempted to investigate the interaction between stock value and macroeconomic factors including interest rate building on this theory. Studies investigating the interaction between interest rates and stock value in different markets and sectors, however, have concluded with contradictory findings.

Most of the studies have reached a conclusion that interest rate negatively impacts the stock performance. For illustration, Amarasinghe (2015) used Granger causality test to explore the causal interaction between stock price and interest rate in the Colombo stock exchange. Outcomes revealed the existence of a unidirectional causal interaction between the tested variables from interest rate to stock price. Analysis further indicated that interest rate negatively impacts stock price index. Jefferis and Okeahalam (2000) studied the cointegration of stock price and selected economic variables, including interest rate, in three African countries; South Africa, Batswana, and Zimbabwe, using Error Correction Model (ECM). They found that higher interest rates have a negative effect on the stock returns in South Africa. Many more empirical researches in different countries have ended with the same conclusion and supported the proposition of the significant negative relationship between the two variables (See for example, Al-Mukit, 2013; Ahmed \& Raoof, 2010; Alam \& Uddin, 2009; Leon, 2008; Rigobon \& Sack, 2004).

There are also several researches that have established a positive relation between the interest rate and stock performance. For example, Iddrisu et al. (2017) examined monetary policy and stock market interactions in 12 countries in Africa using the Vector AutoRegression (VAR) technique. Findings revealed that the monetary policies of the 12 countries had a positive effect on their stock markets across the interest rate channel. Benaković and Posedel (2010) tested the relation between the returns of fourteen stocks in the Croatian capital market and five 
macroeconomic factors, including interest rate, for the period January 2004-October 2009. Results marked a positive relationship between the interest rate and the stock returns. Apergis and Eleftheriou (2002) also tested the relation between stock price and interest rate in Greece from 1988 to 1999 and reported a positive but statistically insignificant relationship. Asprem (1989) argues that the small illiquid financial markets have such a positive relationship. According to Shiller and Beltratti (1992) such a positive relation could be linked to information about potential dividend shifts owing to higher interest rate. For Barsky (1989) the positive relationship may be a function of varying risk premium.

Few other empirical studies have also suggested that there is no relationship between monetary policy aggregates and the stock market performance (See for example: Jasen \& Zervou, 2017; Floro, 2017).

In Egypt, Sourial (2000) tested the relationship between the Egyptian stock market returns and monetary policy using Bayesian VAR models from June 1992 to April 2000. Findings revealed that, until December 1997, the effect of monetary policy on stock market performance was insignificant. After December 1997, a significant correlation between the tested variables was identified.

Focusing on the tourism sector, studies investigating the cointegration of interest rate and tourism stock performance are very rare, and have also ended with contradictory findings, supporting the argument that this is a market case. Chen (2007a) considered the performance of Taiwanese hotel stocks in expansive and contractionary monetary policy settings. Findings indicated that during expansive periods hotel stocks display a greater mean return and reward/risk ratio. In the same contexts the USA, Chen (2010) tested the effect of Federal Reserve policy on the returns of hospitality stocks. He concluded that the impact of the shifts in the discount rate on the returns of hospitality stocks is not strong in general. Chen (2007b) extended his work to china and explored the role of macroeconomic factors in determining hotel stock returns. The outcomes demonstrated the sensitivity of hotel stock returns to the macroeconomic factors in general.

The effects of monetary policy on tourism business performance in four subsectors (airlines, hotels, restaurants and tourism firms) in Hong Kong were also investigated by Chen et al. (2010). Results revealed a strong impact of monetary policy on hotel and tourism stock performance. Chan and Lim (2011) tested the relationship between hospitality and tourism stock price and macroeconomic factors, including discount rate, in New Zealand using Cointegration analysis and Vector Error Correction Model (VECM). They provided empirical evidence on a significant correlation between the discount rate and the stock return of tourism companies. Finally, in Japan, Chen et al. (2012) investigated the impact of macroeconomic factors on hotel stock return in 30 years data period, employing VAR model. Results marked the discount rate as a significant determining factor of the hotel stock return.

\section{Data and Research Methodology}

The data set consists of monthly data collected from 'Monthly Economic Trends' reported by the CBE website and the Egyptian Exchange (EGX) over the period June 2010- September 2019. The monthly weighted average interest rate on the 3-month deposit is used as a proxy for interest rate, as it is seen as an alternative to equity market investment.

Tourism stock performance is proxied by stock price, as a firm stock price reflects its financial health and expectations about future corporate performance (Amarasinghe, 2015). As per September 2019, 18 tourism and hospitality companies are listed and active in the EGX. Measure of stock performance captures the monthly prices of 14 companies. (Remco Tourism Villages Construction Company RTVC; Orascom Development Egypt ORHD; El Wadi for 
Touristic Investment ELWA; Marsa Alam for Tourism Development MMAT; Egyptian Resorts EGTS; Egyptian Company for International Touristic Projects EITP; Golden Pyramids Plaza GPPL; Misr Hotels MHOT; Pyramisa Hotels and Resorts PHTV; Al Rowad ROTO; Trans Oceans Tours TRTO; Sharm Dreams SDTI; Golden Coast Elsokhna for Touristic Investment GOCO; Genial Tours GETO). 4 companies are excluded; 3 companies due to insufficient data (Rowad Misr RMTV; El Shams Pyramids SPHT; Sky Light Touristic Development SLTD), and 1company due to interference with real-estate index (Mena Touristic and the real-estate Investment MENA).

The linear Granger causality test is conducted to establish the dynamic interaction between interest rate (IR) and tourism stock price (SP). Cointegration analysis and Error Correction Model (ECM) are employed to determine the long-run and short-run cointegrations between the research variables (Engle \& Granger, 1987). Variance Decomposition and Impulse Response analysis are also used to quantify the percentage of estimated error variance in SP explained by variation in itself and IR, and trace the effect of an IR shock on tourism firms SP.

\section{Descriptive Statistic}

Table 1 demonstrates the descriptive statistics of the study variables, the mean and the median of (IR) are $9.1 \%$ and $7.8 \%$, respectively, the minimum of IR is $6.9 \%$ and the maximum value is $14.6 \%$. For the tourism companies in the sample the mean and the median of SP are 8.27, 3.39, respectively, with a minimum value of 0.047 and a maximum value of 65.40 .

Table 1: Descriptive Statistics of Variables

\begin{tabular}{|l|c|c|}
\hline & SP & IR \\
\hline Mean & 8.269157 & 0.091027 \\
\hline Median & 3.936077 & 0.078000 \\
\hline Maximum & 65.40000 & 0.146000 \\
\hline Minimum & 0.047000 & 0.069000 \\
\hline Std. Dev. & 10.42973 & 0.024545 \\
\hline Skewness & 2.417319 & 0.950876 \\
\hline Kurtosis & 9.869060 & 2.228832 \\
\hline Jarque-Bera & 3951.232 & 235.8362 \\
\hline Probability & 0.000000 & 0.000000 \\
\hline Observations & 1568 & 1568 \\
\hline
\end{tabular}

Figure 1 presents the line plot for SP over the study period. It can be noticed that stock price data fluctuates with no pattern. Figure 2 depicts the line plot for IR over the study period. It is clear that interest rate data suffers from high volatility. Hence, a formal test of stationary has been conducted. 
Figure1: Line Plot for (SP)

stock price

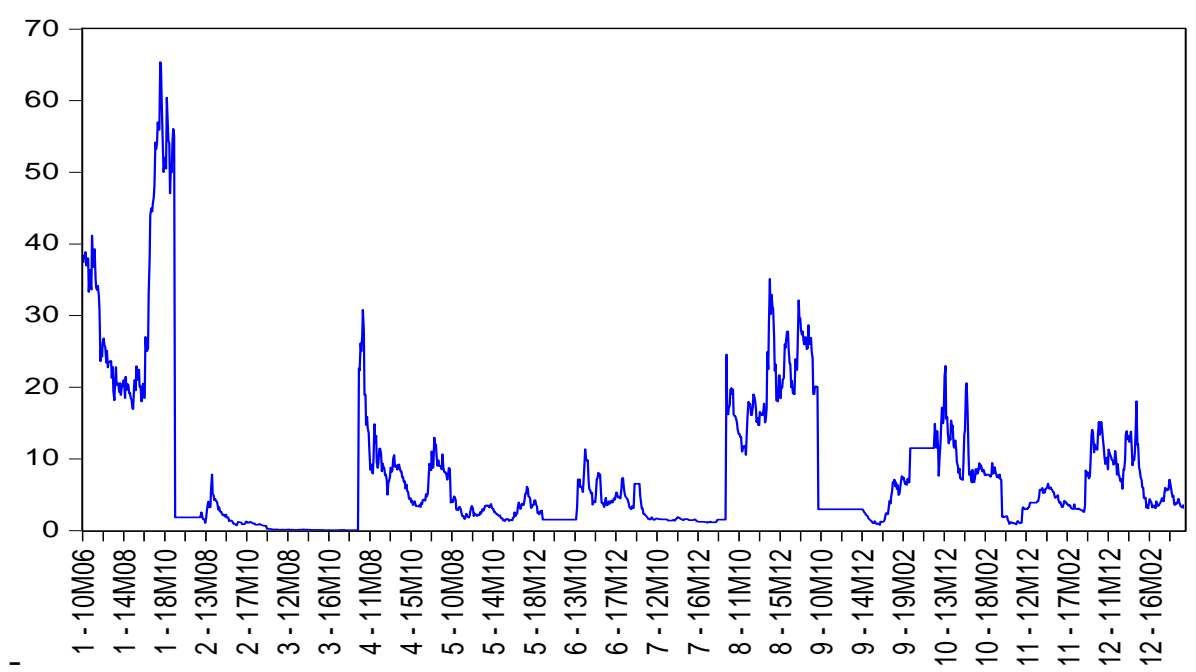

Figure 2: Line Plot for (IR)

interest rates

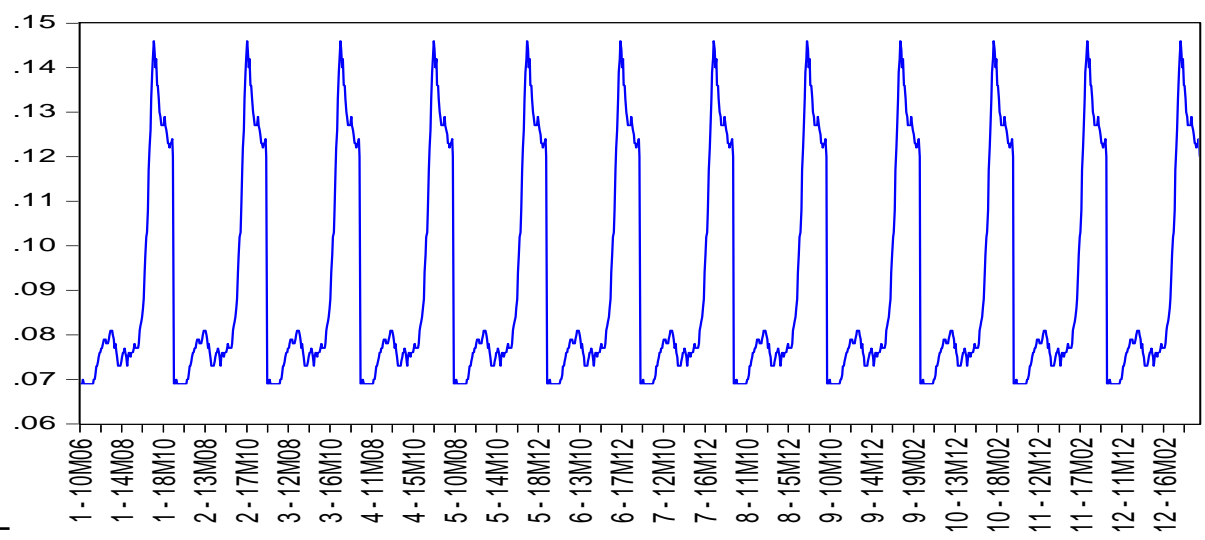

\section{Analysis and Findings}

\section{Unit Root Test}

The stationary assumption is tested as an initial step of the analysis using the Augmented DickeyFuller (ADF) (1981) test. Table 2 reports ADF test results. It can be concluded that the IR data is not stationary at its level. One proposed solution is to take the first difference and perform the test again. The result in this case is in favor of stationary at the $1 \%$ significance level. Tourism SP data is stationary at its level at the $1 \%$ significance level. So, both variables are integrated of order I (1).

Table 2: ADF Test Results

\begin{tabular}{|l|c|c|}
\hline \multicolumn{1}{|c|}{ Variable } & ADF & P-value \\
\hline IR & 16.0607 & 0.8859 \\
First difference of IR & 52.4264 & $0.0007 * * *$ \\
SP & 74.3594 & $0.0000^{* * *}$ \\
\hline
\end{tabular}

****1\% significance.

Note: Schwartz Bayesian lag length selection criterion has been employed 


\section{Linear Granger Causality Test}

Linear Granger causality test is employed to establish the causal relationship between the research variables. It estimates the following regression model:

$$
S P_{t}=\alpha_{0}+\sum_{K=1}^{P} \beta_{1 K} S P_{t-K}+\sum_{K=1}^{P} \beta_{2 K} I R_{t-K}+\varepsilon_{t},
$$

Where $S P_{t}$ is the stock price at time $\mathrm{t}, I R_{t}$ interest rate at time $\mathrm{t}$ and $\alpha_{0}, \beta_{1 K}$ and $\beta_{2 K}$ are regression parameters. The error term $\varepsilon_{t}$ is assumed to be normally distributed and independent. F-statistics for Granger causality test for the null hypotheses which are " $I R_{t}$ does not Granger cause $S P_{t}$ ", and " $S P_{t}$ does not Granger cause $I R_{t}$ ".

As illustrated in table (3) the null hypothesis that IR "does not Granger cause" SP is rejected at the $1 \%$ level of significance while the null hypothesis that SP "does not Granger cause" IR is not rejected at any significance levels. This notes that there is a causality which runs unidirectionally from the IR to the SP of tourism companies.

Table 3: Granger Test Results

\begin{tabular}{|l|c|c|}
\hline \multicolumn{1}{|c|}{+} & F-Statistic & Prob. \\
\hline IR “does not Granger cause" SP & 6.20526 & $0.0003 * * *$ \\
\hline SP “does not Granger cause” IR & 0.69365 & 0.5560 \\
\hline$* * * 1 \%$ significance.
\end{tabular}

\section{Cointegration and ECM Models}

Since the tested variables are I (1), Cointegration analysis and Error Correction Model (ECM) are applied to examine long- run and short-run unbiasedness and efficiency.

Johansen's (1988) procedure is applied to determine the cointegration vectors. Although a variety of cointegration tests exist, Johansen's procedure has an advantage over its counterparts that it considers model variables as endogenous variables. The estimated regression model is;

$$
S P_{t}=\alpha+\delta I R_{t-1}+\varepsilon_{t}
$$

Where $\alpha$ and $\delta$ denotes the cointegration parameters.

The appropriate lag length is specified to be 8 according to Akaike Information Criterion (AIC) and Final Prediction Error (FPE). Considering, 8 lags and a constant in the cointegration relation, the Johansen's Trace test and the Maximum Eigen value test results are reported in tables 4 and 5. According to the results there is a long-run cointegration between the variables under considerations, thus the corresponding ECM model is specified.

Table 4: Trace Test Results

\begin{tabular}{|c|c|c|c|c|}
\hline Hypothesis & Eigenvalue & Trace Statistic & $\begin{array}{c}\text { 0.05Critica1 } \\
\text { Value }\end{array}$ & Prob.** \\
\cline { 1 - 4 } No. of CE(s) & & & 15.49471 & 0.0065 \\
\cline { 1 - 4 } None ${ }^{*}$ & 0.015731 & 21.06623 & 3.841466 & 0.2257 \\
\hline At most 1 & 0.001187 & 1.467680 & \\
\hline
\end{tabular}


International Journal of Heritage, Tourism and Hospitality Vol. (13), No. (2), September, 2019 By: Faculty of Tourism and Hotels, Fayoum University

Table (5): Maximum Eigen value Test Results

\begin{tabular}{|c|c|c|c|c|}
\hline Hypothesized & Eigenvalue & Max-Eigen Statistic & 0.05Critical Value & Prob.** \\
\cline { 1 - 4 } No. of CE(s) & & & & \\
\hline None $*$ & 0.015731 & 19.59855 & 14.26460 & 0.0065 \\
\hline At most 1 & 0.001187 & 1.467680 & 3.841466 & 0.2257 \\
\hline
\end{tabular}

*Rejection at the 0.05 level

**MacKinnon-Haug-Michelis (1999) p-values

Table 6 displays the long-run cointegration regression results. As shown in the table the impact of IR on SP is found to be positive and statistically significant at 5\% level. A rise in IR of $1 \%$ leads the SP to increase by $26.8 \%$.

Table 6: Long- Run Cointegration Results

\begin{tabular}{|c|c|}
\hline Cointegrating Eq & CointEq1 \\
\hline SP(-1) & 1.000 \\
\hline IR(-1) & $26.810^{* *}$ \\
\hline & $(7.68)$ \\
\hline $\mathrm{C}$ & {$[3.49]$} \\
\hline
\end{tabular}

Note: Standard errors in ( ) \& t-statistics in [ ] ** sig. at 5\% level

To find the short-run dynamics for of long-run equilibrium relation, ECM model is estimated

based on the following equation:

$$
\Delta S P_{t}=\rho u_{t-1}+\beta \Delta I R_{t-1}+\sum_{i=2}^{m} \beta_{i} \Delta I R_{t-i}+\sum_{j=1}^{k} \psi_{j} \Delta S P_{t-j}+v_{t}
$$

Where $\quad \Delta S P_{t}=S P_{t}-S P_{t-1}, \Delta I R_{t-1}=I R_{t-1}-I R_{t-2}, u_{t-1}$ is the lagged value of error correction term and $v_{t}$ is a white noise error term.

As shown in table 7 the ECM coefficient specifies that about $0.03 \%$ of the SP deviation from its long-run equilibrium level is adjusted each period in the short-run.

Table 7: Short- Run Cointegration Results

Sample (After adjustment): 2011M02 2019M09

Observations: 1248

\begin{tabular}{|c|c|c|}
\hline Observations: 1248 & D(STOCKPRICE) & D(INTERESTRATES) \\
\hline Error Correction: & 0.000384 & $-1.46 \mathrm{E}-06$ \\
\hline ECM $_{\mathrm{t}-1}$ & $(0.00026)$ & $3.2 \mathrm{E}-07)$ \\
\hline & {$[1.45438]$} & {$[-4.52999]$} \\
\hline & -0.025783 & $3.60 \mathrm{E}-05$ \\
\hline & $(0.02782)$ & {$[3.4 \mathrm{E}-05)$} \\
\hline & {$[-0.92692]$} & {$[1.05855]$} \\
\hline $\mathrm{D}(\mathrm{SP}(-1))$ & 48.99233 & 0.280233 \\
\hline & $(23.9142)$ & {$[0.02923)$} \\
\hline & {$[2.04867]$} & $0.58610]$ \\
\hline $\mathrm{C}$ & -0.032573 & 0.000103 \\
\hline & $(0.04072)$ & {$[5.0 \mathrm{E}-05)$} \\
\hline & {$[-0.79989]$} & {$[2.07407]$} \\
\hline
\end{tabular}

Standard errors in ( ) \& t-statistics in [ ]

Note: lag length selection is based on $\llbracket \Delta \mathrm{SP} \rrbracket_{-} \mathrm{t}$ and $\llbracket \Delta \mathrm{IR} \rrbracket_{\_}(\mathrm{t}-1)$. Hence, the appropriate lag length is 7 
Vector Error Correction (VEC) for autocorrelations and Heteroscedasticity in residuals are performed to estimate the strength of the results. From table 8 no autocorrelation exists for the residuals for all lags. Figure 3 for the visual test also demonstrates that the model is free from auto correlation (almost white noise) which supports the strength of the applied model.

Table 8: VEC Test Results

\begin{tabular}{|c|c|c|}
\hline Lags & LM-Stat & Prob \\
\hline 1 & 2.723729 & 0.6051 \\
\hline 2 & 6.882035 & 0.1423 \\
\hline 3 & 1.103399 & 0.8937 \\
\hline 4 & 8.522975 & 0.0742 \\
\hline 5 & 9.248521 & 0.0552 \\
\hline 6 & 12.59792 & 0.0734 \\
\hline 7 & 6.479183 & 0.1661 \\
\hline 8 & 4.402898 & 0.3542 \\
\hline 9 & 5.235848 & 0.2639 \\
\hline 10 & 8.943339 & 0.0625 \\
\hline 11 & 6.835428 & 0.1448 \\
\hline Probs from chi-square with 4 df. & 4.719725 & 0.3173 \\
\hline
\end{tabular}

Figure 3: Stock Price Residuals

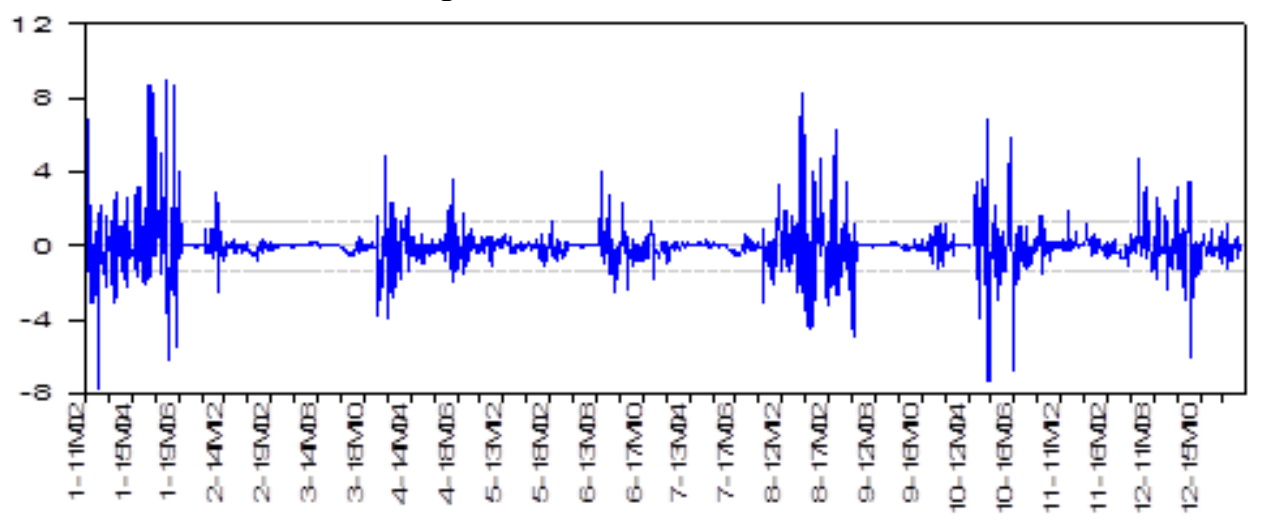

\section{Variance Decomposition and Impulse Response}

Variance Decomposition test is used to assess the contribution of each form of shocks to the variation of forecast errors of SP. As shown in table 9, 100\% of the forecast error variance of SP in the first period seems to be explained by a unit standard deviation shock in the variable itself. However, this percentage decreases in the second period to $99.79 \%$, and the remaining $1.88 \%$ can be explained by the variation in IR. The influence of IR variation seems to be increasing till it reaches $4.5 \%$ at period 10 . Figure 4 demonstrates the impulse response plot. It is clear that the shock of IR positively impact the stock performance of tourism companies in EGX.

Table 8: VD Test Results

\begin{tabular}{|c|c|c|c|}
\hline Period & S.E. & STOCKPRICE & INTERESTRATES \\
\hline 1 & 1.351615 & 100.0000 & 0.000000 \\
\hline 2 & 1.886608 & 99.79753 & 0.202470 \\
\hline 3 & 2.304245 & 99.75809 & 0.241909 \\
\hline
\end{tabular}


International Journal of Heritage, Tourism and Hospitality Vol. (13), No. (2), September, 2019

By: Faculty of Tourism and Hotels, Fayoum University

\begin{tabular}{|c|c|c|c|}
\hline $\begin{array}{c}\text { Period } \\
4\end{array}$ & S.E. & STOCKPRICE & INTERESTRATES \\
\hline 5 & 2.706580 & 99.39858 & 0.601417 \\
\hline 6 & 2.983572 & 98.88900 & 1.111004 \\
\hline 7 & 3.232968 & 98.42077 & 1.579232 \\
\hline 8 & 3.461312 & 97.40539 & 2.594609 \\
\hline 9 & 3.691902 & 96.70914 & 3.290857 \\
\hline 10 & 3.915925 & 95.95759 & 4.042412 \\
\hline
\end{tabular}

Figure 4: Response to Cholesky one S.D Innovations

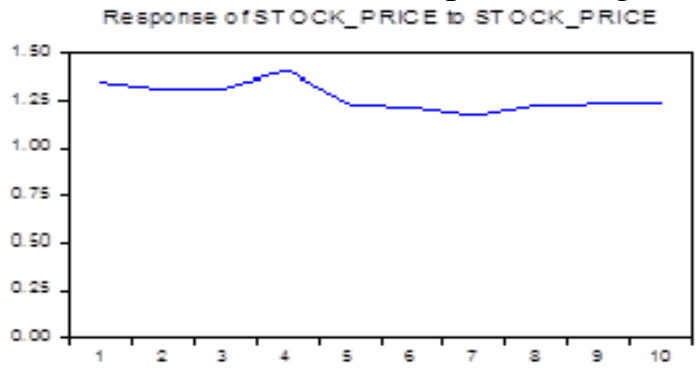

Responge ofST OCK_PRICE to INTEREST_RATES
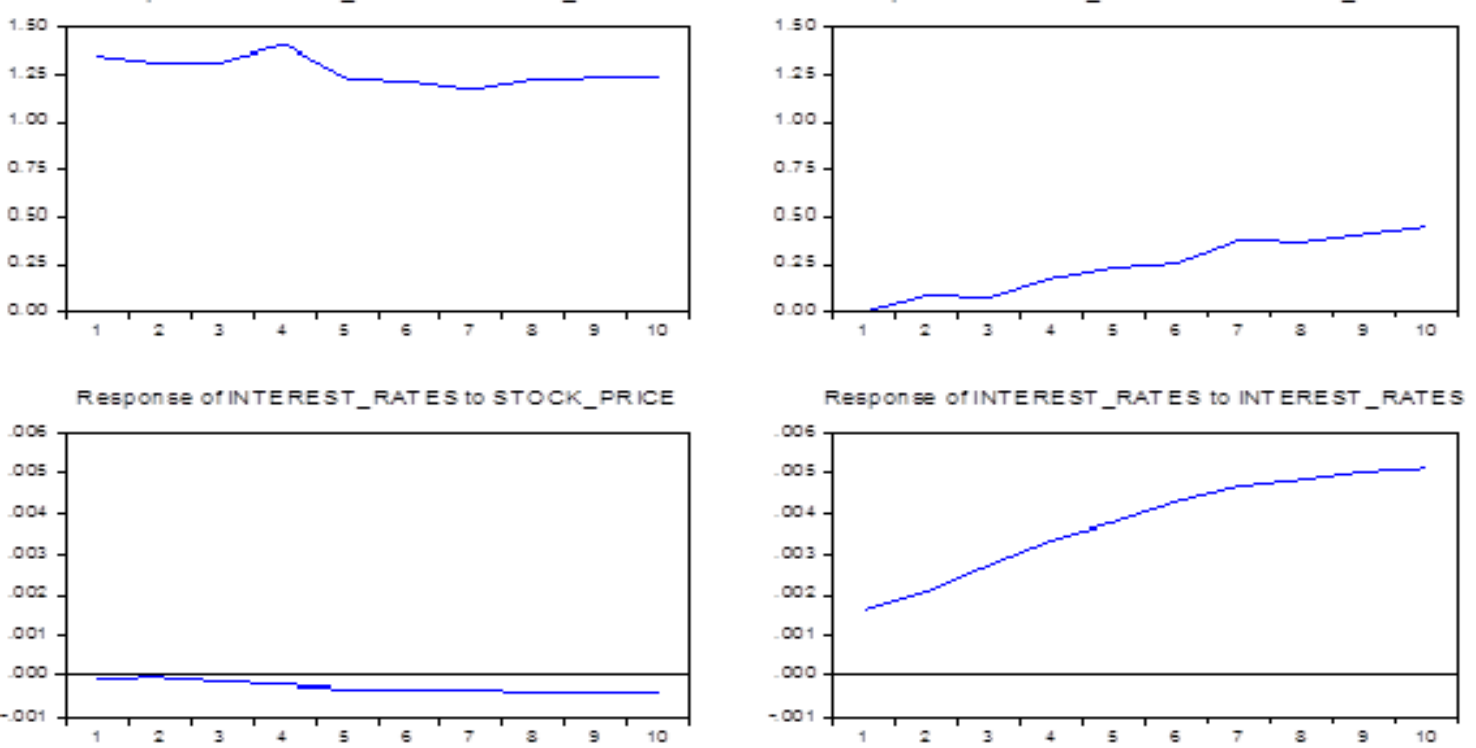

\section{Conclusion and Implications}

The few empirical studies in tourism and hospitality literature that attempt to examine the relationship between monetary policy aggregates and tourism stock performance, end with contradictory results, which implies that it is a market case. Following these empirical research studies, this study attempts to examine the relationship between interest rate and tourism stock performance in the EGX, and estimate the impact of interest rate variations on tourism stock price. Granger causality test detects a unidirectional causal interaction between the variables from interest rate to tourism stock price.

By employing Cointegration analysis a positive long-run relationship between the tested variables is observed, and a rise by $1 \%$ in interest rate leads tourism stock price to increase by $26.8 \%$. The error correction coefficient specifies that about $0.03 \%$ of the tourism stock price deviation from its long-run equilibrium level is adjusted in the short-run. Variance decomposition results show that about $95.16 \%$ of the variation in in the forecast error of stock price is explained by the variation in the variable itself, which suggests that tourism stock price is almost independent.

Though the identification of a positive regression in this study is different from most previous studies, it is consistent with the findings of Asprem (1989), Barsky (1989) and Shiller and Beltratti (1992). The positive relation found between the tested variables may be attributed to several factors including low EGX efficiency, poor marketing infrastructure and information 
flow difficulties. Different studies referred to the weak efficiency form of the EGX market and the problem of information flow as information reaches the market sequentially not simultaneously and it has much noise and speculative trading (Jefferis \& Smith, 2005; El-Ansary \& Atuea, 2012). In a recent study, Ebrahim (2019) empirically examined the role monetary policy plays in achieving the objectives of economic policy in Egypt and noted that the impact of monetary policy on economic policy objectives is insignificant due to lack of channels of transmission of policies to the market. Also, the illiquidity and low prices remain serious problems in the EGX. The specific nature of companies in the tourism sector which impacts their financing behavior may also justify the positive relationship between interest rate and tourism stock performance, in particular, the limited accessibility to debt market and high proprietorship ratio in their financing structure. Lastly, speculation related to expected variations in foreign exchange rates may also have an effect on the stock performance of tourism companies at the tested period. The tested period witnessed a successive rise in foreign exchange rates, mainly, USD rate, which reached very high levels after the free floating decision in November 2016.

These results offer valuable insights for decision-makers at the government level. To ensure tourism and hospitality sector growth, government should device measures to overcome imperfections and inefficiency in the Egyptian stock market and establish a vibrant market that responds adequately to changes in the economic policies through different interaction channels. A marketing strategy for attracting domestic and foreign flows of capital to tourism companies in the EGX is highly required. Moreover, applying a policy to increase the number of publicly listed tourism companies in the EGX is strongly suggested.

For tourism companies' executives, they are advised to consider the systematic risk exposed by the interest rate in forecsasting the stock prices and build strategies to manage their financial positions upon future expected variations in the interest rate in Egypt.

Finally, Researchers should expand their interests to investigate tourism industry integrations and the impact of policies and macroeconomic variables on the performance of tourism sector in general and tourism companies in particular in Egypt, applying econometric models that provide mechanisms for building decisions upon real analysis of data.

\section{References}

Ahmed, M. \& Raoof, A. (2010) "Do Interest Rate, Exchange Rate Effect Stock Returns? A Pakistani Perspective”, International Research Journal of Finance and Economics, 50: 14650 .

Alam, M. \& Uddin, G. (2009) "Relationship between Interest Rate and Stock Price: Empirical Evidence from Developed and Developing Countries”, International Journal of Business and Management, 4(3): 43-51.

Al-Mukit, M. (2013) "The Effects of Interest Rates Volatility on Stock Returns: Evidence from Bangladesh", International Journal of Management Business Research, 3(3): 269-279.

Amarasinghe, AAMD (2015) "Dynamic Relationship between Interest Rate and Stock Price: Empirical Evidence from Colombo Stock Exchange", International Journal of Business and Social Science, 6(4): 92-97.

Apergis, N. \& Eleftheriou, E. (2002) "Interest Rates, Inflation, and Stock Prices: The Case of The Athens Stock Exchange", Journal of Policy Modeling, 24: 231-236.

Asprem, M. (1989) "Stock Prices, Asset Portfolios and Macroeconomic Variables in Ten European Countries", Journal of Banking and Finance, 13, 589-612.

Barsky, R. (1989) "Why Don't The Prices of Stocks and Bonds Move Together? ", American Economy Review, 79: 1132-1145. 
Benaković, D. \& Posedel, P. (2010) "Do Macroeconomic Factors Matter for Stock Returns? Evidence from Estimating a Multifactor Model on the Croatian Market", Business Systems Research, 01(1-2): 1-50.

Central Bank of Egypt (CBE) Website: https://www.cbe.org.eg/en/EconomicResearch/Statistics/ PagesMonthly InterestRatesHistorical.aspx (Last accessed: 15/1/2020)

Chan, F. \& Lim, C. (2011) "Tourism Stock Performance and Macro Factors", 19th International Congress on Modeling and Simulation, Perth, Australia, 12-16 December 2011. http://mssanz.org.au/modsim2011 (accessed on 12/8/2019)

Chen, M. H. (2007a) "Hotel Stock Performance and Monetary Conditions", International Journal of Hospitality Management, 26(3): 588-602.

Chen, M. H. (2007b) "Macro and Non-Macro Explanatory Factors of Chinese Hotel Stock Returns", International Journal of Hospitality Management, 26: 991-1004.

Chen, M. H., Liao C.N. \& Huang S.S. (2010) "Effects of Shifts in Monetary policy on Hospitality Stock Performance", The Service Industries Journal, 30 (2): 171-184

Chen, M. H. (2010) "Federal Reserve Monetary Policy and US Hospitality Stock", Tourism Economics, 16(4): 833-852.

Chen, M.H., Agrusa J., Krumwiede D. \& Lu, H. (2012) "Macroeconomic Influences On Japanese Hotel Stock Returns”, Journal of Hospitality Marketing \& Management, 21(1): 81-99.

Dickey, D.A. \& Fuller, W.A. (1981) "Likelihood Ratio Statistics for Autoregressive Time Series with a Unit Root”, Econometrica, 49(4): 1057-1072.

Ebrahim A. (2019) "The Role of Monetary Policy in Achieving the Objectives of Economic Policy in Egypt Using the Magic Square of Kaldor", JSST, 20(3): 118-154. https://jsst.journals.ekb.eg/article_61398_0d6322a09ae224d5da92f3f611d15e06.pdf (accessed on 10/9/2019)

El-Ansary, O. \& Atuea, M. (2012) "The Effect of Stock Trading Volume on Return in the Egyptian Stock Market", International Research Journal of Finance and Economics, 100: 152-168.

Engle, R., \& Granger, C. (1987) "Co-Integration and Error-Correction: Representation, Estimation and Testing", Econometrica, 55 (2): 251-276.

Floro, D. (2017) "Monetary Policy Surprises and Firm-Level Stock Return Predictability: Evidence From a New Panel-Based Approach" Applied Economics Letters, 25(17): 1-6.

Hashemzadeh, N., \& Taylor, P. (1988) "Stock Prices, Money supply, and Interest Rate: The Question of Causality", Applied Economics, 20: 1603-1611.

Iddrisu, S., Harvey, S. \& Amidu, M. (2017) “The Impact of Monetary Policy on Stock Market Performance: Evidence From Twelve (12) African Countries", Research in International Business and Finance, Elsevier, 42(C): 1372-1382.

Jasen, D. \& Zervou A. (2017) "The Time Varying Effect of Monetary Policy on Stock Returns", Economics Letters, 160: 54-58.

Jefferis, K. \& Okeahalam, C. (2000) "The Impact of Economic Fundamentals on Stock Markets in Southern Africa", Development Southern Africa, 17(1): 23-51.

Jefferis, K. \& Smith, G. (2005) "The Changing Efficiency of African Stock Markets", South African Journal of Economics, 73(1): 54- 67.

Johansen, S. (1988) "Statistical Analysis of Cointegration Vectors", Journal of Economic Dynamics and Control, 12: 231-254.

Leon, N. K. (2008) "The Effects of Interest Rates Volatility on Stock Returns and Volatility: Evidence from Korea”, Euro Journal of Finance and Economics, 14: 285-290. 
Modigliani, F. \& Cohn, R. (1979) “Inflation, Rational Valuation, and the Market", Financial Analysts Journal, 38: 24-44.

Rigobon, R. \& Sack, B. (2004) “The Impact of Monetary Policy on Asset Prices”, Journal of Monetary Economics, 51(8): 1553-1575.

Ross, S. (1976) "The Arbitrage Theory of Capital Asset Pricing", Journal of Economic Theory. 13(3): 341-360. doi: 10.1016/0022-0531(76)90046-6

Shiller, R. J. \& Beltratti, A. E. (1992) "Stock Prices and Bond Yields: Can the Co-movements Be Explained in Terms of Present Value Models? Journal of Monetary Economics, 30: 25-46.

Sourial, M. (2000) "Monetary Policy and Its Impact on Stock Market: The Egyptian Case", Egyptian Ministry of Economy and Foreign Trade, Working Paper No. 156.

Uddin, G. \& Alam, M. (2007) "The Impacts of Interest Rate on Stock Market: Empirical Evidence from Dhaka Stock Exchange", South Asian Journal of Management and Sciences, 1(2): 123-132.

World Travel and Tourism Council WTTC (2019), Egypt 2019 Annual Research: Key Highlights. $\quad$ https://www.wttc.org/economic-impact/country-analysis/countrydata/\#undefined (accessed on 1/8/2019) 